Agro-Science Journal of Tropical Agriculture, Food, Environment and Extension Volume 21 Number 1 (January 2022) pp. $39-44$

ISSN 1119-7455

\title{
STEM PORTION AND NUMBER OF STAKES INFLUENCE ON GROWTH AND YIELD OF CASSAVA VARIETY IN THE SOUTH EAST, NIGERIA
}

\author{
${ }^{1}$ Okpara D.A., ${ }^{1}$ Udeh D.C., ${ }^{\text {2}}$ Akinbo O.K., ${ }^{2}$ Eke-Okoro O.N. and ${ }^{2}$ Olojede A.O. \\ ${ }^{1}$ Department of Agronomy, Michael Okpara University of Agriculture, Umudike, Nigeria \\ ${ }^{2}$ National Root Crops Research Institute, Umudike, Nigeria \\ *Corresponding's author's email: oladunniakinbo@yahoo.com
}

\begin{abstract}
Investigations were conducted to study the effect of stem portion and number of stakes per stand on crop establishment, growth and yield of cassava variety NR 8082 in Umudike Southeastern Nigeria during the 2016/17 and 2017/18 cropping seasons. In each year, the experiment was laid out as a $3 \times 3$ factorial, in randomized complete block design with three replications. Treatments consisted of three stem portions of different physiological ages (top, middle and basal) and three numbers of stakes per stand (1, 2 and 3). The middle and basal stem portions significantly increased percent establishment, plant height and leaf area index at 3 months after planting (MAP) but had no effect on number of storage roots per plant. The best stem portion for storage root yield was, however, the top portion which produced the highest yield on average. Number of stakes per stand did not significantly affect stem girth, number of nodes per plant and leaf area index, but the use of 1 stake per stand increased number of storage roots per plant, root weight and storage root yield in 2017/2018 cropping season. Number of stakes per stand did not significantly influence storage root yield across the two seasons of evaluation. Interactions between stem portion and number of stakes per stand did not significantly affect storage root yield of NR 8082 high cassava variety in both cropping seasons. Based on the findings, the use of 1 stake per stand is recommended for high root yields of NR 8082 cassava variety under conditions of low soil fertility in Umudike, South East Nigeria. Although the top portion enhanced root yield, farmers could use any of the stem portions, since the middle and basal parts gave satisfactory yields and had better establishment than the former.
\end{abstract}

Key words: stem portion, number of stakes, cassava, root yield, Southeast Nigeria

\section{INTRODUCTION}

Cassava (Manihot esculentus Crantz) is a perennial woody shrub which is primarily grown as annual crop in the humid tropics (Bellotti et al., 2011; ElSharkawy, 2012). In Africa, cassava is the single most important source of dietary energy for large proportion of the population (Cock, 2011). Tufan (2013) reiterated that no other continent depends on cassava to feed as many as 500 million people daily as Africa. It is a major food crop in Nigeria and is strategically valued for its role in food security, poverty alleviation and as source of raw material for agro-allied industries with huge potential for export market (CEDP, 2005; Egesi et al., 2006). As human food, cassava root is prepared in various forms such as garri, fufu and tapioca; as major industrial raw material, it is used for production of starch, alcohol, pharmaceutics, gums, confectionaries and livestock feed (Eke-Okoro et al., 1999). The leaves and tender shoots are important sources of vitamins, minerals and proteins. Despite its importance, yields in farmers' fields are low due to low soil fertility or use of inappropriate agronomic practices (Eke-Okoro, 1997; Okpara et al., 2010).
In any production system, the size and quality of stakes are of fundamental importance for high yield (Eke-Okoro et al., 2001). It has been affirmed that the stem part from which cutting is taken has effect on the yield of cassava (Chan et al., 1983). A mature cassava stem has three stem sections, namely, the hardwood (basal portion), semihardwood (middle portion) and shoot tip (top portion). Shoot tips are very fragile and have high mortality rate especially if they are subjected to stress during the first month after planting. This is because they have high water content and dehydrate rapidly. Cock (1985) reported that stake selection is important in achieving high stable yield. The use of the basal part of the stem for planting rather than the terminal portion has been suggested (Jennings, 1970) but the intrinsic merit of the basal part is not obvious except that it is the oldest tissue on the stem. Legese et al. (2011) realized the highest yield from the main stem top part whereas the least yield was obtained from main stem basal part. However, Leihner (1983) studied the influence of tissue age and found that stakes from middle and lower part of the primary

Please cite as: Okpara D.A., Udeh D.C., Akinbo O.K., Eke-Okoro O.N. and Olojede A.O. (2022). Stem portion and number of stakes influence on growth and yield of cassava variety in the South East, Nigeria. Agro-Science, 21 (1), 39-44. DOI: https://dx.doi.org/10.4314/as.v21i1.7 
stem (older stakes) sprouted much faster and were more vigorous than stakes from the upper portion of primary stems and from secondary stems (younger stakes). CIAT (1979) reported that in early branching varieties, younger stakes (middle and upper portion of plant) gave greater yields.

The number of shoots per stand of cassava is likely to influence growth, development and yield stability in cassava either by competition between these shoots for nutrients and space or by increase in photosynthetic surfaces arising from production of more branches or leaves by the multiple shoots or stems (Enyi, 1972a,b). These factors are likely to increase or reduce growth rate of individual shoots. Cassava stakes when planted usually produced many shoots which may give rise to competition for resources. The competition may be checked by reducing the number of shoots arising at emergency in order to prevent a reduction in the yield of multishoot plants. Shanumugha and Srinivasan (1973) investigated the influence of number of shoots per plant on the growth and yield of cassava and found that plants with two shoots out yielded the single and multi-shoot plants, registering narrow root ratio. Eke-Okoro (1997) and NRCRI (2011) also reported that increasing shoot number from one to two per stand improved growth and yield of cassava. In the traditional farming systems, farmers usually plant one or more stakes per stand but the effect of such a practice on cassava productivity may depend on such factors as cultivar, cultural practices, quality of planting materials and location (Udealor and Asiegbu, 2006). Although the top part of the stem is susceptible to dehydration and reduced establishment, it sprouts early and establishes once growing conditions are optimum (Onwueme and Sinha, 1991), while the number of stakes per stand may modify the growing condition and influence crop establishment, growth and root yields, depending on the environment (Eke-Okoro, 1997). This study seeks to explore ways of integrating the best stem portion and number of stakes per stand to maximize yield. The objective was to examine the effects of stem portion, number of stakes per stand and interactions between both factors on the growth and yield of cassava variety NR 8082 in Southeast Nigeria.

\section{MATERIALS AND METHODS}

The study was conducted in 2016/17 and 2017/18 cropping seasons at National Root Crops Research Institute (NRCRI), Umudike Farm, Southeastern Nigeria. Umudike is located on $5^{\circ} 29^{\prime} \mathrm{N}$ and $7^{\circ} 32^{\prime} \mathrm{E}$ and on an altitude of $122 \mathrm{~m}$ asl. The site used in $2016 / 17$ was a sandy loam with $61 \%$ sand, $20 \%$ silt, $19 \%$ clay, $4.4 \mathrm{pH}$ (water), $2.4 \%$ organic matter, $0.12 \% \mathrm{~N}, 39.9 \mathrm{mg} \mathrm{kg}^{-1} \mathrm{P}$ and $0.27 \mathrm{cmol} \mathrm{kg}^{-1}$. In $2017 / 18$, it was loamy sand with $81 \%$ sand, $12 \%$ silt, $7 \%$ clay, $5.5 \mathrm{pH}$ (water), $0.8 \%$ organic matter, $0.056 \% \mathrm{~N}, 13.8 \mathrm{mg} \mathrm{kg}^{-1} \mathrm{P}$ and $0.11 \mathrm{cmol} \mathrm{kg}^{-1} \mathrm{~K}$.
Treatments consisted of all possible combinations of 3 levels of cassava stem portions (the top, middle and basal) and 3 levels of number of stakes per stand (1,2 and 3 stakes). They gave a total of 9 treatment combinations. The experiment was a $3 \times 3$ factorial in a randomized complete block design with three replicates. The treatment combinations were randomly allocated to the plots. Each plot measured $5 \times 6 \mathrm{~m}\left(30 \mathrm{~m}^{2}\right)$. During $2016 / 2017$ cropping season, cassava was planted on 6 June while in 2017/2018 cropping season, it was planted on 7 September. The cassava stems were cut and separated into different stem portions (top, middle and basal). When the circumference of the base region became narrower, it was regarded as the starting point of the middle region and where the circumference of the middle region became still narrower, it was regarded as the starting point of the top region Eke-Okoro (1997) for the 12 months old cassava stem used, the basal section was dark brown, the middle section, brown and the top, light brown or green. The cassava stakes were planted on the crest of the ridges, using the inclined or slanting method of planting with buds facing upwards and two-third buried into the ridges. The planting space at $1.0 \times 1.0 \mathrm{~m}$ which gave a plant population of 10,000 plants per hectare for 1 stake per plant, 20,000 plants per hectare for 2 stakes per plant and 30,000 plants per hectare for 3 stakes per stand planting. After planting, the field was sprayed the following day with pre-emergence herbicide $\left(\right.$ El-Tarazine ${ }^{\circledR}$ ) at $150 \mathrm{ml} 20 \mathrm{~L}^{-1}$ water and post emergence herbicide $\left(\right.$ Tackle $^{\circledR}$ ) at $200 \mathrm{ml} 20 \mathrm{~L}^{-1}$ water to check weeds. The active ingredient of ElTarazine ${ }^{\circledR}$ is atrazine while the active ingredients of Tackle $^{\circledR}$ are imazethapyr and glyphosate. Supplementary weeding was done at 2, 5 and 9 months after planting (MAP). Supply of vacant stands was done at 6 weeks after planting (WAP). A blanket application of fertilizer NPK 15:15:15 at the rate of $400 \mathrm{~kg} \mathrm{ha}^{-1}$ was applied at $2 \mathrm{MAP}$.

Measurements taken included establishment count at 2 MAP, plant height and leaf area index at 3, 6 and 9 MAP in 2016/17 only, number of storage roots, storage root weight per plant $(\mathrm{kg})$ and root yield $\left(\mathrm{t} \mathrm{ha}^{-1}\right)$ at 12 MAP in 2016/17 and 2017/18 cropping seasons. Crop establishment was estimated as percent of stands per plot with shoot greater than $10 \mathrm{~cm}$ above soil level. Five plants per plot were randomly selected, tagged and used for measuring plant height and leaf area while data on root yield and yield components were taken from all plants in the two inner rows per plot. Leaf area (LA) which was used to estimate leaf area index (LAI) was obtained by multiplying the product of length and breadth of the median leaflet of the number of leaflets on the leaf (Spencer, 1962). The regression model, $\mathrm{LA}=1.933+0.907 \mathrm{LB}$ with $R^{2}$ as 0.974 , was used to measure leaf area, where $L$ is length of 
median leaflet, B is breadth of median leaflet (Karim et al., 2010). Leaf area index was established by dividing the leaf area per plant by the ground covered (Watson, 1952). Data collected were analyzed according to the procedure for a factorial experiment in randomized complete block design (RCBD) outlined by Steele and Torrie (1980). Treatment means were separated by the use of Fisher's Least Significant Difference test at 5\% level of probability using GenStat (2007) statistical package.

\section{RESULTS}

In $2016 / 17$, the basal stem portion had significantly higher percent crop establishment than the middle portion which in turn had higher crop establishment than the top portion (Table 1).

However, in 2017/18, there was no difference in percent establishment with respect to the middle and basal stem portions, but they had higher establishment than the top portion. Crop establishment decreased significantly when the number of stakes was increased from 1 to 3 stakes per stand. There were significant interactions in 2017/18. At all number of stakes per stand progressing from the top to basal portion, there was a significant increase in crop establishment. Crop establishment was generally higher in 2017/18 $(54 \%)$ than in $2016 / 17$ (27.6\%).
At 3 MAP in 2016/17, the basal and middle stem portions maintained similar plant height, which was significantly higher than that of the top portion (Table 2). However, at 9 MAP, the basal stem cuttings had taller plants than the middle portion. The effect of number of stakes per stand was such that no significant differences occurred at 3 and 6 MAP, but at 9 MAP, 3 stakes per stand produced significantly taller plants than 2 stakes. In general, plant height increased with plant age up to 9 MAP.

Leaf area index at 3 MAP was significantly highest with the basal stem cuttings while the top had the lowest (Table 3). Stem portion did not produce leaf area index that varied significantly from each other at 6 and 9 MAP. There were also no differences in leaf area index with respect to number of stakes per stand. Leaf area index rose with plant age to attain maximum value at 6 MAP and thereafter declined at 9 MAP.

There were no significant effects of stem portion on number of storage roots in both cropping seasons (Table 4). However, the number of stakes per stand had significant effect, such that 1 stake gave higher number of tuberous roots than 2 or 3 stakes per stand. 2 and 3 stakes per stand maintained similar number of storage roots in both cropping seasons. There were no significant interactions between stem portion and number of stakes per stand on the number of storage roots produced.

Table 1: Effect of stem portion and number of stakes per stand on establishment (\%) at 2 months after planting (MAP)

\begin{tabular}{|c|c|c|c|c|}
\hline \multicolumn{5}{|c|}{ Number of stakes per stand } \\
\hline Stem portion & 1 & 2 & 3 & Mean \\
\hline & \multicolumn{4}{|c|}{$2016 / 2017$} \\
\hline Top & $7.8(15.78)$ & $8.3(16.60)$ & $6.3(14.38)$ & 7.5 \\
\hline Middle & $35.6(36.12)$ & $32.2(34.50)$ & $24.1(29.18)$ & 30.6 \\
\hline Basal & $60.0(50.18)$ & $43.4(41.18)$ & $30.7(33.67)$ & 44.7 \\
\hline Mean & $34.5(34.23)$ & $28.0(30.76)$ & $20.4(25.75)$ & 27.6 \\
\hline \multicolumn{5}{|c|}{$2017 / 2018$} \\
\hline Top & $68.8(56.52)$ & $42.8(40.83)$ & $27.0(31.09)$ & 46.2 \\
\hline Middle & $91.1(73.24)$ & $48.3(44.03)$ & $32.6(34.79)$ & 57.3 \\
\hline Basal & $93.3(75.37)$ & $49.4(44.68)$ & $32.9(35.02)$ & 58.5 \\
\hline \multirow[t]{5}{*}{ Mean } & $84.4(68.38)$ & $46.8(43.18)$ & $30.8(33.63)$ & 54.0 \\
\hline & $\operatorname{LSD}_{(0.05)}$ & $2016 / 17$ & $2017 / 18$ & \\
\hline & Stem portion $(\mathrm{P})$ means & 7.25 & 6.85 & \\
\hline & Number of stakes (S) means & 7.25 & 6.85 & \\
\hline & $\mathrm{P} \times \mathrm{S}$ means & 12.55 & NS & \\
\hline
\end{tabular}

Values in parenthesis are arcsine transformed data. NS - not significant

Table 2: Effect of stem portions and number of stakes per stand on plant height $(\mathrm{cm})$ at different sampling dates $2016 / 17$

\begin{tabular}{lccc}
\hline & \multicolumn{3}{c}{ Months after planting } \\
Stem portion & 3 & 6 & 9 \\
\hline Top & 58.6 & 119.9 & 147.0 \\
Middle & 71.9 & 125.4 & 141.7 \\
Basal & 75.8 & 123.8 & 149.6 \\
Mean & 68.7 & 123.0 & 146.1 \\
LSD $_{(0.05)}$ & 10.8 & NS & 5.9 \\
Number of stakes per stand & & & \\
1 & 65.9 & 120.8 & 146.3 \\
2 & 74.1 & 122.4 & 141.7 \\
3 & 66.2 & 125.9 & 150.2 \\
Mean & 68.7 & 123.0 & 146.1 \\
LSD $_{(0.05)}$ & NS & NS & 5.9 \\
\hline NS - not significant $^{3}$ \\
\hline
\end{tabular}

Table 3: Effect of stem portions and number of stakes per stand on leaf area index at different sampling dates in 2016/17

\begin{tabular}{lccc} 
& \multicolumn{3}{c}{ Months after planting } \\
Stem portion & 3 & 6 & 9 \\
\hline Top & 0.193 & 0.851 & 0.540 \\
Middle & 0.461 & 0.799 & 0.522 \\
Basal & 0.611 & 0.663 & 0.451 \\
Mean & 0.422 & 0.773 & 0.504 \\
LSD $_{(0.05)}$ & 0.138 & $\mathrm{NS}$ & $\mathrm{NS}$ \\
Number of stakes per stand & & & \\
1 & 0.377 & 0.863 & 0.563 \\
2 & 0.436 & 0.650 & 0.492 \\
3 & 0.452 & 0.806 & 0.459 \\
Mean $_{\text {LSD }}(0.05)$ & 0.422 & 0.773 & 0.504 \\
\hline NS - not significant & $\mathrm{NS}$ & $\mathrm{NS}$ & $\mathrm{NS}$ \\
\hline
\end{tabular}


In both cropping seasons, top stem portion had significantly higher storage weight per plant than the middle or basal stem cuttings (Table 5). The middle and basal stem cuttings did not vary in tuberous root weight. In 2016/17, there were no differences in root weight between the numbers of stakes, although, root weight seemed to decrease with increasing number of stakes per stand. However, in $2017 / 18$, increasing the number of stakes from 1 to 2 or 3 stakes per stand caused significant reduction in storage root weight. In both seasons, interactions were not significant on root weight per plant.

In both cropping seasons, storage root yield in tons per hectare followed similar trends in response to stem portion (Table 6). However, in 2016/17 the top stem portion produced significantly higher root yield than the middle and basal cuttings. Storage root yields of the middle and basal stem cuttings were not significantly different in both cropping seasons. There were no differences in storage root yield with respect to number of stakes in 2016/17, but in 2017/18, 1 stake per stand had significantly higher root yield of cassava than planting 2 and 3 stakes per stand. The 2 and 3 stakes per stand maintained comparable root yields.

Table 4: Effect of stem portion and number of stakes per stand on number of storage roots per plant

\begin{tabular}{|c|c|c|c|c|}
\hline \multirow[b]{2}{*}{ Stem portion } & \multicolumn{3}{|c|}{ Number of stakes per stand } & \multirow[b]{2}{*}{ Mean } \\
\hline & 1 & 2 & 3 & \\
\hline \multicolumn{5}{|c|}{$2016 / 2017$} \\
\hline Top & 9.20 & 6.67 & 5.93 & 7.27 \\
\hline Middle & 8.43 & 3.63 & 3.23 & 5.10 \\
\hline Basal & 9.50 & 4.57 & 3.27 & 5.78 \\
\hline Mean & 9.04 & 4.96 & 4.14 & 6.05 \\
\hline \multicolumn{5}{|c|}{$2017 / 2018$} \\
\hline Top & 9.27 & 5.47 & 2.73 & 5.82 \\
\hline Middle & 8.90 & 6.20 & 4.53 & 6.54 \\
\hline Basal & 14.27 & 6.10 & 4.90 & 8.42 \\
\hline Mean & 10.81 & 5.92 & 4.06 & 6.93 \\
\hline \multicolumn{2}{|c|}{$\operatorname{LSD}_{(0.05)}$} & $2016 / 17$ & $2017 / 18$ & \\
\hline \multicolumn{2}{|c|}{ Stem portion $(\mathrm{P})$ means } & NS & NS & \\
\hline \multicolumn{2}{|c|}{ Number of stakes $(\mathrm{S})$ means } & 1.97 & 2.40 & \\
\hline \multicolumn{2}{|c|}{$\mathrm{P} \times \mathrm{S}$ means } & NS & NS & \\
\hline
\end{tabular}

NS - not significant

Table 5: Effect of stem portion and number of stakes per stand on storage root weight $(\mathrm{kg})$ per plant

\begin{tabular}{|c|c|c|c|c|}
\hline \multicolumn{5}{|c|}{ Number of stakes per stand } \\
\hline Stem portion & 1 & 2 & 3 & Mean \\
\hline \multicolumn{5}{|c|}{$2016 / 2017$} \\
\hline Top & 0.519 & 0.495 & 0.387 & 0.467 \\
\hline Middle & 0.251 & 0.308 & 0.391 & 0.317 \\
\hline Basal & 0.402 & 0.276 & 0.219 & 0.299 \\
\hline Mean & 0.391 & 0.360 & 0.332 & 0.361 \\
\hline \multicolumn{5}{|c|}{$2017 / 2018$} \\
\hline Top & 0.494 & 0.341 & 0.288 & 0.374 \\
\hline Middle & 0.330 & 0.235 & 0.211 & 0.259 \\
\hline Basal & 0.265 & 0.235 & 0.199 & 0.233 \\
\hline Mean & 0.363 & 0.270 & 0.233 & 0.289 \\
\hline \multicolumn{2}{|c|}{$\operatorname{LSD}_{(0.05)}$} & $2016 / 17$ & $2017 / 18$ & \\
\hline \multirow{2}{*}{\multicolumn{2}{|c|}{ Stem portion $(\mathrm{P})$ means }} & 0.143 & 0.057 & \\
\hline Number of stakes (S) means & & s NS & 0.057 & \\
\hline \multicolumn{2}{|c|}{$\mathrm{P} \times \mathrm{S}$ means } & NS & NS & \\
\hline
\end{tabular}

NS - not significant
Table 6: Effect of stem portion and number of stakes per stand on storage root yield $\left(\mathrm{t} \mathrm{ha}^{-1}\right)$

\begin{tabular}{|c|c|c|c|c|}
\hline & Number o & of stakes per & tand & \\
\hline Stem portion & 1 & 2 & 3 & Mean \\
\hline & & $2016 / 2017$ & & \\
\hline Top & 46.9 & 65.1 & 56.1 & 56.0 \\
\hline Middle & 20.8 & 20.4 & 37.6 & 26.3 \\
\hline Basal & 36.6 & 25.3 & 21.9 & 27.9 \\
\hline Mean & 34.8 & 36.9 & 38.5 & 36.7 \\
\hline & & $2017 / 2018$ & & \\
\hline Top & 47.8 & 37.6 & 23.3 & 36.2 \\
\hline Middle & 28.3 & 29.2 & 28.5 & 28.7 \\
\hline Basal & 37.0 & 28.7 & 29.3 & 31.7 \\
\hline Mean & 37.7 & 31.8 & 27.0 & 32.2 \\
\hline $\operatorname{LSD}_{(0.05)}$ & & $2016 / 17$ & $2017 / 18$ & \\
\hline Stem portion ( & P) means & 14.35 & NS & \\
\hline Number of sta & kes (S) means & Is NS & 8.70 & \\
\hline $\mathrm{P} \times \mathrm{S}$ means & & NS & NS & \\
\hline
\end{tabular}

Table 7: Effect of stem portion and number of stakes stand ${ }^{-1}$ on storage root yield $\left(\mathrm{t} \mathrm{ha}^{-1}\right)$ for the two seasons

\begin{tabular}{lcccc}
\hline \multicolumn{5}{c}{ Number of stakes per stand } \\
Stem portion & 1 & 2 & 3 & Mean \\
\hline Top & 47.3 & 51.3 & 39.7 & 46.1 \\
Middle & 24.5 & 24.8 & 33.1 & 27.5 \\
Basal & 36.8 & 27.0 & 25.6 & 29.8 \\
Mean & 36.2 & 34.4 & 32.8 & 34.5 \\
& & & \\
$\operatorname{LSD}_{(0.05)}$ for stem portion (P) means & 10.9 & \\
$\operatorname{LSD}_{(0.05)}$ for number of stakes (S) means & $\mathrm{NS}$ & \\
$\operatorname{LSD}_{(0.05)}$ for P $\times$ S means & $\mathrm{NS}$ & \\
\hline
\end{tabular}

NS - not significant

Stem portion and number of stakes per stand inter-actions were not significant on storage root yield in both seasons. Averaged over the two seasons, the trend for storage root yield was for the top portion to produce significantly higher yield than the middle and basal cuttings (Table 7).

Planting the top stem portion gave storage root yield that was greater by $67.6 \%$ for the middle and $54.7 \%$ for the basal cuttings. The middle and basal stem cuttings always had significantly similar tuberous root yields. Cassava stem portion and number of stakes per stand did not produce significant interaction effects on storage root yield.

\section{DISCUSSION}

Crop growth attributes such as plant height and leaf area index were greatly enhanced by the middle and basal stem portions than the top portion, due to the better establishment that conferred an advantage on the former. This trend agrees with the report of George et al. (2001), that stem pieces obtained from the older parts of the plant established more rapidly while pieces from very young parts of the stem do not root readily in the field. Akoroda et al. (1997) noted that establishment ability of the genotype and the category of stakes that are planted will greatly influence survival on the date of harvest. The better establishment and higher vegetative growth from the basal stem portions did not reflect correspondingly on the yield of storage roots, indicating that age of stem pieces was an important factor in determining growth and root yield in cassava. 
Leaf area index dropped at 9 MAP due to loss of lower leaves during the dry season and senescence. Eke-Okoro (1997) made similar observations.

Stem portion had profound effect on storage root yield, with the highest yield obtained from the top portion. Legese et al. (2011) reported similar results. However, Eke-Okoro et al. (1999) and Chan et al. (1983) obtained the highest fresh root yield from the middle portion, contrary to the result of this investigation. The apparent differences in response to stem portion reported by different investigators may be related to such factors as the age of stem pieces and the cultivar. For instance, Eke-Okoro et al. (1999) did not indicate the age of the stem but the cultivars (TMS 30572, TMS 91934 and NR 8083) used in their study were different from the 12 months old stem of the NR 8082 variety used in present study. Akoroda et al. (2006) indicated the need to reduce the number of basal stakes used if they are too woody, as these would have very low meristematic activity, and recommended the use of 6-9 MAP cassava stems for planting. To improve rooting and consequently the establishment of the top portion which produced optimum yield, Onwueme and Sinha (1991) stressed the need to allow tender shoot tips root in mist chamber before transplanting them to the field.

Yields of fresh storage root were highest with 1 stake per stand in one year, but across the two seasons, yields did not differ significantly for number of stakes per stand. On the other hand, the number of storage roots and root weight decreased as the population density increased. This suggests that number of tubers and tuber weight per plant were dictated primarily by competition with neighboring plants for light or nutrient or both. Okpara et al. (2014) observed that when competition became intense in yam and hence, limiting the availability of environmental resources to the individual plants, it ultimately leads to high intra plant competition for assimilates, resulting in a reduction in number and weight of tubers. In a soil of higher nutrient status ( $\mathrm{pH}, 5.4-6.5$; N, 0.14-0.16\%), EkeOkoro (1997) reported higher yields when cassava was planted at 2 stakes per stand, indicating that soil fertility is an important factor in determining the yield response to number of stakes per plant. There was no yield advantage in the use of 3 stakes per stand over 1 or 2 stakes per stand, probably because of the stiffer competition and greater plant remobilization of assimilates for shoot growth in the former. Shanumugha and Srinivasan (1973) attributed the low cassava yields from multiple shoot production to the production of tiny roots and faster rate of soil-resources depletion. For the soil of this investigation, which had low $\mathrm{N}$ of $0.056-0.12 \%$ and a $\mathrm{pH}$ of 4.4-5.5, the use of more than one stake per stand seemed unnecessary since no yield improve- ments occurred at higher planting rates. Storage root yield did not appear to vary between the two cropping seasons but crop establishment was higher in 2017/2018 in which planting was done late in September, due probably to better moisture regime at this period. Ezedinma et al. (1981) obtained higher dry matter yields from September plantings and concluded that the best time to plant cassava is during the late rather than the early cropping season.

\section{CONCLUSION}

In conclusion, under the condition of this study, the results demonstrated that stem portion had significant effects on cassava crop establishment, plant height, leaf area index, storage root weight and yield. The middle and basal stem cuttings had better and higher crop establishment, plant height, and leaf area index than the top portion. However, the top stem portion produced the highest root yield and is recommended, provided measures are taken to improve the establishment of this stem part. (e.g rooting in mist chamber before transplanting). On the other hand, crop establishment decreased when the number of stakes was increased to 3 stakes per stand but 3 stakes produced taller plants than 1 or 2 stakes per stand. In one out of two years, 1 stake per stand had higher root yield than planting 2 or 3 stakes per stand. Across the two cropping seasons, there were no differences in storage root yield due to numbers of stakes per plant. Based on this result, it is recommended that 1 stake per stand should be adopted for cassava production in Umudike and area with similar agro-ecosystem in South eastern Nigeria. Despite the enhanced root yield from the top portion, farmers are advised to use the different stem parts in cassava production, as the middle and basal stem portions had satisfactory yields and better crop establishment than the former.

\section{REFERENCES}

Akoroda M.O., Ocitti P., Obwoya C. and Hahn S.K. (1997). Screening cassava genotypes for field establishment ability. Discovery \& Innovation, 9, 39-45

Akoroda M.O., Oyadiran T.F., Yomeni M.O., Okoro E. and Dixon A.G.O. (2006). Pattern of stake weight along the stem axis from its base and non-emergence of planted stakes. Proc. $40^{\text {th }}$ Conf. Agric. Soc. Nig., Abia State, pp. 758-763

Balagopalan C. (2002). Cassava utilization in food, feed and industry. In: Hillock R.J., Thresh J.M. and Bellotti A.C. (eds.), Cassava: Biology, Production and Utilization (pp. 301-318). USA: CAB International

Bellotti A.C., Herrera C.J., Hernandez M.P., Arias B., Guerrero J.M. and Melo E.I. (2011). Cassava pest in latin America, Africa and Asia. In: Howeler R.H. (ed.), The Cassava Handbook (pp. 199-257). Thailand: Centro International de Agricultura Tropical (CIAT), A Reference Manual Based on the Asian Regional Cassava Training 
CEDP (2005). Cassava Enterprise Development Project. Additional Funding Program Description submitted to United State Agency for International Development (USAID) - Nigeria Mission and the Shell Development Company (SPDC) - Nigeria by the IITA, pp. 2-4, Ibadan, Nigeria

Chan S.K., Hussein K.M., Lian G.S. and Pians L.N. (1983). Planting for Maximum Yield: A Special Report on Cassava in Pennisular Malaysia with Particular Reference to Production Technique. Kuala Lumper: Malaysian Agricultural Research and Development Institute Report No. PTM-02-83, pp. 1-20

CIAT (1979). Centro International de Agricultura Tropicale. Cali Columbia: Annual Report from 1979, pp. $1-100$

Cock J.H. (1985). Stability of performance of cassava genotypes. Cassava Breeding: A Multidisciplinary Review. Proc. Workshop, 4- $7^{\text {th }}$ March, Philippines, pp. $177-206$

Cock J.H. (2011). Cassava: A basic energy sources in the tropics. In: Howeler R.H. (ed.), The Cassava Handbook: A Reference Manual Based on the Asian Regional Cassava Training Course (p. 23). Thailand: Centro International de Agricultural tropics (CIAT)

Egesi C., Mbanaso E., Ogbe F., Okogbenin E. and Fregene M. (2006). Development of cassava varieties with high value root quality through induced mutations and market-aided breeding. Annual Report of National Root Crops Research Institute (NRCRI), Umudike - Nigeria, pp. 2-6

Eke-Okoro O.N. (1997). Studies on Growth and Some Factors Influencing Yield in Nigerian cassava Varieties. A PhD Thesis of the University of Nigeria, Nsukka, pp. 262

Eke-Okoro O.N., Okereke O.U. and Okeke J.E. (1999). Effect of weather change and planting set on growth and productivity of cassava in Southeastern Nigeria. Afr. J. Root Tuber Crop., 3 (2), 34-38

Eke-Okoro O.N., Okereke O.U. and Okeke J.E. (2001). Effect of stake size on some growth indices and yield of three cassava cultivars. J. Agric. Sci., 137, 419-426

El-Sharkawy M.A. (2012). Stress tolerance cassava: The role of integrative ecophysiology-breeding research in crop improvement. Open J. Soil Sci., 2, 162-186

Enyi B.A.C. (1972a). The effect of spacing on growth, development and yield of single and multi-shoot plants of cassava: Root tuber yield and attributes. East Afr. Agric. Forest. J., 38, 23-26

Enyi B.A.C. (1972b). The effect of spacing on growth, development and yield of single and multi-shoot plants of cassava: Physiological factors. East Afr. Agric. Forest. J., 38, 15-28

Ezedinma F.O.C., Ibe D.G. and Onwuchuruba A.I. (1981). Performance of cassava in relation to time of planting and harvesting. In: Tropical Root Crops: Research Strategies for the 1980s. Proc. $1^{\text {st }}$ Triennial Root Crops Symp. of the Int. Soc. Trop. Root Crops Africa Branch (ISTRAC - AB), Ibadan, Nigeria 8-12 Sep., 1980
GenStat (2007). GenStat Discovery Edition 3. UK: Lawes Agricultural Trust, Rothamsted Experimental Station

George I., Mohankumar C.R., Nair G.M. and Ravindran C.S. (2001). Cassava agronomy research and adoption of improved practices in India: Major achievements during the past 30 years. In: Howeler R.H. and Tan S.L. (eds.), Cassava's Potential in Asia in the $21^{\text {st }}$ Century: Present Situation and Future Research and Development Needs (pp 279-299). Proc. $6^{\text {th }}$ Region. Workshop, Hochi Minhcity, Feb. 21-25, Vietnam

Jennings D.L. (1970). Cassava in Africa. Field Crops Abstracts, 23, 271-278

Karim M.R., Fakir M.S.A., Mostata M.G. and Prodhan A.K.M.A. (2010). Leaf area estimation by linear regression models in cassava. J. Agron. Environ., 4, $17-22$

Legese H., Gobeze I., Shegro A. and Geleta N. (2011). Impact of planting position and planting materials on root yield of cassava (Manihot esculenta Crantz). $J$. Agric. Sci. Technol., 5, 448-454

Leihner D.E. (1983). Physiology problems in the production of cassava planting material. Proc. Region. Workshop, Centro Int. Agric. Trop., 13-16 September, Cali, Colombia, pp. 27-72

NRCRI (2011). Proposed Work Plan on Research in Cassava/Yam Presented to NARP Management Committee (p. 53), National Root Crops Research Institute, Umudike, Nigeria

Okpara D.A., Agoha U.S. and Iregbu M. (2010). Response of cassava variety TMS98/0505 to potassium fertilization and time of harvest in Southeastern Nigeria. Nig. Agric. J., 41, 84-92

Okpara D.A., Ikoro A.I., Mbah E. and Akpaninyang F. (2014). Growth and yield of white yam microsett in response to plant population and NPK fertilizer. Nig. J. Crop Sci., 2, 72-76

Onwueme I.C. and Sinha T.D. (1991). Field Crop Production in Tropical Africa. Netherlands: CTA, pp. 232-233

Shanumugha A. and Srinivasan C. (1973). Influence of number of shoot per plant on the growth and yield of cassava. Farm J. India, 14 (7), 147-152

Spencer B. (1962). A rapid method for estimating leaf area of cassava using linear measurement. Trop. Agric., 39, 147-152

Steel G.D. and Torrie J.H. (1980). Principles and Procedures of Statistics: A Biometrical Approach ( $2^{\text {nd }}$ ed.). New York: McGraw-Hill Book Company Inc., p. 633

Tufan H.A. (2013). Next generation cassava breeding project. Retrieved 31 Mar. 2015 from: http://www.nextgenecassava.org/about.html

Udealor A. and Asiegbu J.E. (2005). Effect of cassava genotype and planting pattern of vegetable cow pea on growth, yield and productivity. Nig. Agric. J., 36, 88-96

Watson D.J. (1952). The physiological basis of variation in yield. Adv. Agron., 4, 101-145 